\title{
Suplementasi Inulin Umbi Gembili dengan Lactobacillus plantarum (Sinbiotik) terhadap Nisbah Daging-Tulang Ayam Broiler
}

\section{Supplementation Inulin of Gembili Tuber with Lactobacillus plantarum (Synbiotic) on Meat- Bone Ratio of Broiler Chicken}

\author{
D. R. Sari*, E. Suprijatna, S. Setyaningrum, dan L. D. Mahfudz \\ Fakultas Peternakan dan Pertanian, Universitas Diponegoro \\ Kampus Tembalang, Semarang 50275 - Indonesia \\ *E-mail: ratnad741@gmail.com \\ (Diterima: 24 Juli 2019; Disetujui: 13 September 2019)
}

\begin{abstract}
ABSTRAK
Tujuan penelitian adalah mengkaji pengaruh penambahan sinbiotik dari inulin ekstrak umbi Gembili dengan bakteri Lactobacillus plantarum terhadap bobot daging dan tulang serta nisbah daging-tulang karkas ayam broiler. Materi yang digunakan yaitu 144 day old chik (DOC) unsexed dengan bobot badan awal 45,68 $\pm 1,52 \mathrm{~g}$. Penelitian menggunakan metode eksperimen dengan menggunakan rancangan acak lengkap yang terdiri dari 4 perlakuan dan 6 ulangan. Perlakuan yang diberikan adalah penambahan sinbiotik sebagai berikut: T0 (ransum basal), T1 (ransum basal + sinbiotik $1 \mathrm{ml} / 100 \mathrm{~g}$ ransum), T2 (ransum basal + sinbiotik $2 \mathrm{ml} / 100 \mathrm{~g}$ ransum) dan T3 (ransum basal + sinbiotik $3 \mathrm{ml} / 100 \mathrm{~g}$ ransum). Parameter yang diamati yaitu bobot daging dan tulang serta nisbah daging-tulang karkas. Data dianalisis dengan Analysis of Variance (ANOVA). Hasil penelitian menunjukkan bahwa perlakuan berpengaruh nyata $(\mathrm{P}<0,05)$ meningkatkan bobot daging, bobot tulang serta nisbah daging-tulang karkas ayam broiler. Dosis $3 \mathrm{ml} / 100 \mathrm{~g}$ ransum menghasilkan bobot daging, bobot tulang serta nisbah daging-tulang tertinggi. Kesimpulan penelitian ini adalah penambahan sinbiotik dari inulin umbi gembili dengan bakteri Lactobacillus plantarum $3 \mathrm{ml} / 100 \mathrm{~g}$ ransum dapat digunakan sebagai aditif pakan dalam pemeliharaan ayam broiler.
\end{abstract}

Kata kunci: ayam Broiler, inulin Gembili, Lactobacillus plantarum, nisbah daging tulang, sinbiotik

\section{ABSTRACT}

The purpose of this study was to examine the effect of synbiotic inulin Gembili tuber extract with Lactobacillus plantarum bacteria on meat and bone weight and meat-bone ratio of broiler carcass. The material used was 144-day old chicks unsexed with the initial body weight of $45.68 \pm 1.52 \mathrm{~g}$. A completely randomized design was used with 4 treatments and 6 replications. The treatment given were addition of synbiotics as follows: T0 (basal ration), $T 1$ (basal ration + synbiotic $1 \mathrm{ml} / 100 \mathrm{~g}$ ration), T2 (basal ration + synbiotic $2 \mathrm{ml} / 100 \mathrm{~g}$ ration) and T3 (basal ration + synbiotic $3 \mathrm{ml} / 100 \mathrm{~g}$ ration). The parameters observed were meat weight, bone weight and meat-bone ratio of carcass. The data were analyzed by Analysis of Variance $(A N O V A)$. The results showed that the treatment significantly $(P<0.05)$ increased meat weight, bone weight and meat-bone ratio of broiler chicken carcass. In conclusion, the addition of synbiotics from Gembili tuber inulin with Lactobacillus plantarum $3 \mathrm{ml} / 100 \mathrm{~g}$ ration can be used as feed additive in the rearing broiler chicken.

Keywords: Broiler chicken, inulin of Gembili, Lactobacillus plantarum, meat bone ratio, synbiotic 


\section{PENDAHULUAN}

Ayam broiler memiliki kemampuan produksi daging yang tinggi dan dapat dipanen dalam waktu 29 hari dengan bobot $1,76 \mathrm{~kg}$ (Wirawan et al., 2019). Kelemahan ayam broiler yaitu rendahnya daya tahan tubuh yang mengakibatkan penyakit mudah menyerang dan mudah stres akibat pengaruh lingkungan. Antibiotic Growth Promoter (AGP) sudah menjadi solusi dari masalah tersebut namun penggunaannya dapat mengakibatkan resistensi terhadap mikroorganisme dan residu pada produk ternak sehingga dapat menimbulkan bahaya bagi kesehatan konsumen (Sarangi et al., 2016). Penggunaan AGP ini sudah dilarang diberbagai negara, di Indonesia sudah dilarang oleh pemerintah per Januari 2018. Maka perlu mencari alternatif pengganti AGP yaitu dengan penggunaan sinbiotik yang aman, yang merupakan kombinasi sinergis antara prebiotik dan probiotik (Dunislawska et al., 2017).

Senyawa-senyawa yang merupakan sumber prebiotik antara lain fruktooligosakarida (FOS), laktulosa, isomaltooligosakarida, laktosukrosa, pyro-dextrins, soy oligosakarida, transgalaktooligosakarida dan inulin (Azhar, 2009). Prebiotik yang paling banyak di teliti adalah inulin. Inulin tidak dapat dihidrolisis oleh enzim pencernaan namun dapat difermentasi oleh mikroba dalam saluran pencernaan sehingga dapat meningkatkan pertumbuhan probiotik dan menekan bakteri patogen (Zubaidah dan Akhadiana, 2013). Salah satu sumber inulin adalah umbi gembili, yang memiliki kadar inulin tinggi yaitu sebesar 67,66\% (Zubaidah dan Akhadiana, 2013). Indonesia memiliki produksi umbi Gembili yang tinggi yaitu 180 ton berdasarkan data Kementrian Pertanian tahun 2013. Namun, Produksi yang tinggi ini belum dimanfaatkan dengan baik oleh masyarakat. Sedangkan BAL banyak ditemukan dalam usus. BAL digunakan sebagai sumber probiotik. Sumber probiotik yang biasa digunakan adalah BAL dengan genus Bifidobacterium dan
Lactobacillus (Haryati, 2011).

Penggunaan sinbiotik berfungsi untuk meningkatkan populasi bakteri asam laktat (BAL) dalam usus. BAL memproduksi asam laktat yang berperan dalam penurunan $\mathrm{pH}$ di dalam usus (Purbarani et al., 2019). pH usus yang rendah mengakibatkan pertumbuhan bakteri patogen tertekan sehingga saluran pencernaan menjadi lebih sehat (Beski dan Sardary, 2015). Selain itu akan mengaktifkan enzim-enzim pencernaan yang akan meningkatkan kecernaan nutrisi khususnya kecernaan protein, serta meningkatkan penyerapan protein dan kalsium, sehingga deposisi protein dan kalsium dalam pembentukan daging dan tulang akan meningkat (Hafeez et al., 2017; Yang et al., 2005). Peningkatan deposisi protein dan kalsium ini diharapkan akan meningkatkan bobot dan daging serta nisbah daging-tulang karkas ayam broiler. Sehingga, penggunaan sinbiotik ini diharapkan dapat menjadi alternatif pengganti AGP.

Beberapa penelitian penggunaan sinbiotik sebagai alternatif pengganti AGP telah dilakukan. Penelitian Dibaji et al. (2014) menunjukkan bahwa penambahan sinbiotik (Biomin Imbo) dalam pakan dapat meningkatkan jumlah bakteri menguntungkan seperti Lactobacillus dan asam laktat dan menurunkan E. Coli dan Coliform. Penelitian Krismiyanto et al. (2014) menunjukkan bahwa pemberian inulin dari umbi dahlia nyata meningkatkan populasi BAL dan pertambahan bobot badan harian $(\mathrm{PBBH})$, menurunkan $\mathrm{pH}, E$. coli serta laju digesta menjadi lebih lambat. Penelitian Mohammed et al. (2018) menunjukkan bahwa penggunaan sinbiotik pada level tertinggi $1,0\left(2 \times 10^{6} \mathrm{cfu} / \mathrm{g}\right)$ $\mathrm{g} / \mathrm{kg}$ pakan nyata meningkatkan bobot badan, PBBH dan konsumsi pakan. Penelitian Asemi et al. (2017) membuktikan bahwa penggunaan sinbiotik dapat meningkatkan penyerapan dan bioavailabilitas mineral seperti kalsium dan fosfor dalam mineralisasi tulang. Penelitian Yousif (2015) menunjukkan bahwa penggunaan sinbiotik tidak berpengaruh nyata terhadap nisbah daging-tulang potongan 
komersial ayam broiler.

Penelitian bertujuan untuk mengkaji pemanfaatan sinbiotik dari inulin ekstrak umbi gembili (IEUG) dengan bakteri Lactobacillus plantarum terhadap bobot tulang dan daging serta nisbah daging dan tulang karkas ayam broiler.

\section{METODE}

Penelitian menggunakan 144 anak ayam unsexed yang memiliki bobot badan $45,68 \pm 1,52 \mathrm{~g}$, ransum basal serta sinbiotik dari bakteri Lactobacillus plantarum dengan inulin ekstrak umbi gembili (IEUG). Bahan ransum yang digunakan yaitu jagung kuning, bungkil kedelai, bekatul, meat bone meal (MBM) serta inulin ekstrak umbi gembili. Umbi gembili diperoleh dari petani lokal daerah Pati, Jawa Tengah dan Lactobacillus plantarum diperoleh dari Lembaga Ilmu Pengetahuan Indonesia (LIPI). Ransum yang digunakan selama penelitian disusun dengan kandungan energi metabolisme (EM) $3.038,33 \mathrm{kkal} / \mathrm{kg}$ dan protein kasar (PK) 22,08 $\%$. Komposisi dan kandungan nutrisi ransum disajikan pada Tabel 1. Kandungan nutrisi umbi Gembili tersaji pada Tabel 2.

\section{Rancangan Percobaan}

Penelitian menggunakan metode eksperimen dengan rancangan acak lengkap (RAL) yang terdiri dari 4 perlakuan dan 6 ulangan (6 ekor per unit). Perlakuan yang diberikan adalah pemberian sinbiotik masingmasing sebagai berikut:

$$
\begin{aligned}
& \mathrm{T} 0=\text { ransum basal (kontrol) } \\
& \mathrm{T} 1=\text { ransum basal }+ \text { sinbiotik } 1 \mathrm{ml} / 100 \mathrm{~g} \\
& \text { ransum } \\
& \mathrm{T} 2=\text { ransum basal }+ \text { sinbiotik } 2 \mathrm{ml} / 100 \mathrm{~g} \\
& \text { ransum } \\
& \mathrm{T} 3=\text { ransum basal }+ \text { sinbiotik } 3 \mathrm{ml} / 100 \mathrm{~g} \\
& \text { ransum }
\end{aligned}
$$

\section{Pelaksanaan penelitian}

Sinbiotik dibuat dengan cara mencampurkan IEUG sebanyak 7\% dengan Lactobacillus plantarum sebanyak $10 \%$ dari volume IEUG. Sinbiotik yang telah dibuat diinkubasi dengan suhu $37^{\circ} \mathrm{C}$ selama 24 jam. Sinbiotik diberikan pada pagi hari. Pencampuran sinbiotik kedalam pakan dilakukan dengan cara mengambil 60 gram pakan dari total kebutuhan pakan dalam satu hari. Sinbiotik yang berupa cairan diambil dengan menggunakan spuit sesuai dengan kebutuhan sinbiotik, kemudian dicampurkan kedalam pakan hingga homogen. Pakan yang sudah dicampur dengan sinbiotik selanjutnya diberikan pada ayam dalam satu pen.

Penelitian dilakukan selama 42 hari. Perlakuan diberikan sejak ayam umur 1 hari. Air minum diberikan secara adlibitum. Vaksinasi ND diberikan umur 2 hari dan ulangan umur 16 hari.

\section{Parameter yang Diamati}

Pengamatan data bobot daging dan tulang dilakukan pada akhir pemeliharaan, saat ayam berumur 42 hari. Sebagai sampel digunakan satu ekor ayam tiap unit percobaan. Ayam dipuasakan terlebih dahulu sebelum dipotong selama 12 jam, selanjutnya ayam dipotong, dicelupkan dalam air hangat dengan suhu $80{ }^{\circ} \mathrm{C}$ selama kurang lebih dua menit, dilakukan pencabutan bulu, dikeluarkan vicera dan dipotong leher serta kaki untuk mendapatkan karkas (Sukmawati et al., 2015). Selanjutnya setelah didapatkan karkas, dilakukan pengamatan data terhadap bobot daging, bobot tulang serta nisbah dagingtulang karkas.

Parameter yang diamati yaitu:

1) Bobot daging

Bobot daging karkas diperoleh dengan penimbangan daging karkas ayam yang dilakukan setelah dipisahkan dengan tulang (Rahmawati et al., 2018). Rumus bobot daging adalah sebagai berikut :

Bobot daging $(\mathrm{g})=$ Bobot karkas $(\mathrm{g})-$ Bobot tulang $(\mathrm{g})$

2) Bobot tulang

Tulang karkas ayam yang sudah dibersihkan dan dipisahkan dengan dagingnya direbus pada air mendidih $100^{\circ} \mathrm{C}$ selama 
Tabel 1. Ransum basal penelitian

\begin{tabular}{|c|c|}
\hline Bahan pakan & Persentase \\
\hline Jagung & 48,00 \\
\hline Bekatul & 12,90 \\
\hline Bungkil kedelai & 28,00 \\
\hline MBM & 10,80 \\
\hline Mineral mix & 0,30 \\
\hline Jumlah & 100,00 \\
\hline \multicolumn{2}{|l|}{ Nutrisi (\%) } \\
\hline EM (kkal/kg) & $3.038,33$ \\
\hline Protein Kasar²) & 22,08 \\
\hline Lemak Kasar $^{2)}$ & 3,53 \\
\hline Serat Kasar ${ }^{2)}$ & 5,19 \\
\hline Kalsium ${ }^{3)}$ & 1,00 \\
\hline Phosphor $^{2)}$ & 0,68 \\
\hline Arginin $^{4)}$ & 1,54 \\
\hline Methionin ${ }^{4}$ & 0,37 \\
\hline $\operatorname{Lisin}^{4)}$ & 1,22 \\
\hline
\end{tabular}

Keterangan: ${ }^{1}$ Dihitung berdasarkan rumus Balton (1967) yang disitasi oleh Sugiharto et al. (2018)

${ }^{2)}$ Hasil analisis proksimat di Laboratorium Ilmu Nutrisi dan Pakan, Fakultas Peternakan dan Pertanian, Universitas Diponegoro, 2018

3) Hasil analisis di Laboratorium Che-mix Pratama, 2019

4) Berdasarkan Tabel NRC, 1994

Tabel 2. Kandungan nutrisi umbi Gembili (dalam 100 gram)

\begin{tabular}{lc}
\hline Zat gizi & Jumlah \\
\hline Protein(g) & 1,10 \\
Lemak $(\mathrm{g})$ & 0,20 \\
Karbohidrat $(\mathrm{g})$ & 31,30 \\
Serat $(\mathrm{g})$ & 1,00 \\
Abu $(\mathrm{g})$ & 14,00 \\
Kalsium(mg) & 56,00 \\
Fosfor(mg) & 0,60 \\
Besi(mg) & - \\
Vit B1(mg) & 4,00 \\
Vit C(mg) & 66,40 \\
Beta Karoten(SI) & 0,08 \\
Air(g) & 85,00 \\
\hline
\end{tabular}

Sumber: Sabda et al. (2019)

10 menit. Sisa daging yang menempel

ditiriskan dan dikeringkan dalam suhu ruang pada tulang dilepas lalu tulang dan daging selama 24 jam. Setelah air hilang, selanjutnya 
dilakukan penimbangan tulang dan diperoleh bobot tulang (Rahmawati et al., 2018).

3) Nisbah antara daging dan tulang

Nisbah daging dan tulang yaitu perbandingan banyaknya daging yang dihasilkan pada setiap satuan tulang (Samsudin et al., 2012). Nisbah daging dan tulang dapat dihitung dengan rumus:

Nisbah daging tulang $=\frac{\text { Produksi Daging }(\mathrm{g})}{\text { Produksi Tulang }(\mathrm{g})}$

4) Massa protein daging

Massa protein daging diperoleh dengan perhitungan kandungan protein daging dikalikan dengan bobot daging (Abdurrahman et al., 2016). Rumus massa protein daging:

Massa protein daging $=$ kadar protein daging (\%) $\mathrm{x}$ bobot daging $(\mathrm{g})$

5) Deposisi protein daging

Deposisi protein daging diperoleh dengan perhitungan menggunakan rumus:

Deposisi protein daging $=$

Massa protein daging (g)

$\overline{\text { (konsumsi protein }(\mathrm{g}) \times \mathrm{kecernaan}(\%))} \times 100 \%$

\section{Analisis Data}

Data kemudian dianalisis dengan analisis ragam menggunakan uji-F, dilanjutkan uji wilayah ganda Duncan.

\section{HASIL DAN PEMBAHASAN}

Rataan bobot daging dan tulang serta nisbah daging-tulang karkas akibat penambahan sinbiotik inulin ekstrak umbi gembili (IEUG) dengan bakteri Lactobacillus plantarum tersaji pada Tabel 3.

\section{Bobot Daging}

Hasil penelitian suplementasi inulin umbi Gembili dengan bakteri Lactobacillus plantarum (sinbiotik) terhadap bobot daging tersaji pada Tabel 3. Penambahan sinbiotik berpengaruh nyata $(\mathrm{P}<0,05)$ meningkatkan bobot daging karkas. Peningkatan yang nyata terjadi pada perlakuan T2 dan T3, sedangkan antar perlakuan T0 sampai level T1 tidak menunjukkan perbedaan nyata. Nilai bobot daging berkisar antara 516,17-730,33 g, tertinggi terdapat pada perlakuan T3 yaitu $730,33 \mathrm{~g}$.

Peningkatan nilai bobot daging ini menunjukkan bahwa penambahan sinbiotik mampu meningkatkan penyerapan nutrisi sehingga meningkatkan deposisi protein kedalam jaringan otot yang menyebabkan adanya peningkatan bobot daging. Hasil penelitian ini sesuai dengan penelitian Salah et al. (2018) yang menunjukkan bahwa penggunaan sinbiotik mampu meningkatkan bobot daging karkas. Penambahan sinbiotik inulin ekstrak umbi Gembili dengan bakteri Lactobacillus plantarum kemungkinan meningkatkan populasi BAL dalam saluran pencernaan. Hal ini sesuai dengan Zubaidah dan Akhadiana (2013) yang menyatakan bahwa penggunaan inulin sebagai prebiotik dapat meningkatkan pertumbuhan bakteri Lactobacillus plantarum, Lactobacillus casei dan Bifidobacterium. Peningkatan populasi BAL akan meningkatkan SCFA, akibatnya terjadi penurunan $\mathrm{pH}$ dalam usus. Hal ini sesuai dengan pendapat Cheng et al. (2017) yang menyatakan bahwa penggunaan prebiotik dan probiotik sebagai sinbiotik dapat menghambat kolonisasi bakteri patogen dengan $\mathrm{pH}$ yang rendah akibat adanya produksi asam lemak volatil.

Penurunan $\mathrm{pH}$ akan menekan bakteri patogen sehingga kesehatan meningkat dan mengaktifkan enzim-enzim pencernaan sehingga kecernaan dan penyerapan nutrisi khususnya protein dan kalsium meningkat. Hafeez et al. (2017) dan Yang et al. (2005) menyatakan bahwa probiotik dengan prebiotik akan bertahan dalam usus sehingga populasi mikroba yang menguntungkan meningkat dan bakteri patogen tertekan, sehingga kecernaan dan penyerapan nutrien optimal. Dengan demikian, deposisi protein kedalam jaringanjaringan otot meningkat. Hal ini sesuai dengan pendapat Abdurrahman et al. (2016) yang menyatakan bahwa penggunaan sinbiotik 
Tabel 3. Bobot daging, bobot tulang, nisbah daging-tulang, massa protein daging serta deposisi protein daging karkas ayam Broiler yang diberi penambahan sinbiotik dari inulin umbi Gembili dengan bakteri Lactobacillus plantarum

\begin{tabular}{lrrrr}
\hline \multirow{2}{*}{ Parameter } & \multicolumn{4}{c}{ Perlakuan } \\
\cline { 2 - 5 } & $\mathrm{T} 0$ & $\mathrm{~T} 1$ & $\mathrm{~T} 2$ & $\mathrm{~T} 3$ \\
\hline Bobot daging $(\mathrm{g})$ & $516,17^{\mathrm{c}}$ & $567,33^{\mathrm{c}}$ & $647,00^{\mathrm{b}}$ & $730,33^{\mathrm{a}}$ \\
Bobot tulang (g) & $79,83^{\mathrm{c}}$ & $87,00^{\mathrm{c}}$ & $95,83^{\mathrm{b}}$ & $107,50^{\mathrm{a}}$ \\
Nisbah daging-tulang & $6,47^{\mathrm{c}}$ & $6,52^{\mathrm{bc}}$ & $6,74^{\mathrm{ab}}$ & $6,79^{\mathrm{a}}$ \\
Massa protein daging(g) & $130,58^{\mathrm{c}}$ & $150,13^{\mathrm{c}}$ & $196,01^{\mathrm{b}}$ & $232,15^{\mathrm{a}}$ \\
Deposisi protein daging(\%) & $40,75^{\mathrm{c}}$ & $41,73^{\mathrm{bc}}$ & $49,23^{\mathrm{ab}}$ & $53,28^{\mathrm{a}}$ \\
\hline
\end{tabular}

Keterangan: Superskrip berbeda pada baris yang sama menunjukkan perbedaan nyata $(\mathrm{P}<0.05)$. T0 $=$ ransum basal (kontrol); $\mathrm{T} 1=$ ransum basal + sinbiotik $1 \mathrm{ml} / 100 \mathrm{~g}$ ransum; $\mathrm{T} 2=$ ransum basal + sinbiotik $2 \mathrm{ml} / 100 \mathrm{~g}$ ransum; T3 = ransum basal + sinbiotik $3 \mathrm{ml} / 100 \mathrm{~g}$ ransum.

dari inulin dengan Lactobacillus sp. dapat meningkatkan deposisi protein. Peningkatan deposisi ini akan mengakibatkan peningkatan bobot daging.

Peningkatan bobot daging didukung dengan kadar protein dan massa protein daging yang nyata $(\mathrm{P}<0,05)$ meningkat pada perlakuan T3 sebesar $31,80 \%$ dan $115,91 \mathrm{~g}$ (Nagara et al., 2019). Dengan demikian, pada penelitian ini penambahan sinbiotik dari IEUG dengan Lactobacillus plantarum mampu meningkatkan bobot daging pada level minimal $3 \mathrm{ml} / 100 \mathrm{~g}$ ransum.

\section{Bobot Tulang}

Hasil penelitian suplementasi inulin umbi Gembili dengan bakteri Lactobacillus plantarum (sinbiotik) terhadap bobot tulang tersaji pada Tabel 3. Penambahan sinbiotik berpengaruh nyata $(\mathrm{P}<0,05)$ meningkatkan bobot tulang karkas. Peningkatan yang nyata terjadi pada perlakuan T2 dan T3, sedangkan antar perlakuan T0 sampai level T1 tidak menunjukkan perbedaan nyata. Nilai bobot tulang berkisar antara 79,83-107,50 g, tertinggi terdapat pada perlakuan T3 yaitu $107,50 \mathrm{~g}$.

Hasil penelitian ini sesuai dengan penelitian Scholz-Ahrens et al., (2007) yang menyatakan bahwa penggunaan prebiotik dan probiotik dalam pakan dapat meningkatkan penyerapan mineral khususnya kalsium. Hal ini sesuai dengan pendapat Hafeez et al. (2017) bahwa penggunaan sinbiotik akan bekerja secara sinergis antara prebiotik dan probiotik yang berakibat pada meningkatnya kecernaan dan penyerapan nutrien. Hal ini menunjukkan bahwa penambahan sinbiotik dari IEUG dengan Lactobacillus plantarum meningkatkan penyerapan kalsium, sehingga retensi mineral mengalami peningkatan, akibatnya deposisi kalsium kedalam tulang meningkat. Hal ini sesuai dengan pendapat Scholz-Ahrenz et al. (2007) bahwa penggunaan prebiotik dan probiotik akan mengakibatkan peningkatan penyerapan mineral akibat adanya peningkatan bakteri yang memproduksi short chain fatty acid (SCFA). Peningkatan deposisi kalsium ini akan mengakibatkan peningkatan bobot tulang karkas.

Peningkatan bobot tulang didukung dengan peningkatan secara nyata $(\mathrm{P}<0,05)$ pada kadar dan massa kalsium daging. Kadar kalsium dan massa kalsium tertinggi terdapat pada perlakuan T3, yaitu sebesar $1,36 \%$ dan 4,95g (Nagara et al., 2019). Dengan demikian, pada penelitian ini penambahan sinbiotik dari IEUG dengan Lactobacillus plantarum mampu meningkatkan bobot tulang pada level minimal $3 \mathrm{ml} / 100 \mathrm{~g}$ ransum.

\section{Nisbah Daging - Tulang}

Hasil penelitian suplementasi inulin umbi Gembili dengan bakteri Lactobacillus 
plantarum (sinbiotik) terhadap nisbah dagingtulang tersaji pada Tabel 3. Penambahan sinbiotik berpengaruh nyata $(\mathrm{P}<0,05)$ meningkatkan nisbah daging-tulang karkas ayam broiler. Peningkatan yang nyata baru terjadi pada T2, sedangkan T0 dan T1 tidak berbeda nyata. Peningkatan nilai nisbah daging-tulang pada penelitian ini tidak terlalu tajam, karena peningkatan bobot daging juga diikuti peningkatan bobot tulang yang tinggi. Nilai nisbah daging-tulang berkisar antara $6,47-6,79$, tertinggi pada perlakuan T3 yaitu 6,79 .

Hasil penelitian ini berbeda dengan penelitian Yousif (2015) bahwa penggunaan sinbiotik tidak berpengaruh terhadap nisbah daging-tulang. Hal ini disebabkan karena level sinbiotik yang digunakan pada penelitian ini lebih tinggi yaitu ransum basal + sinbiotik 1 $\mathrm{ml} / 100 \mathrm{~g}, 2 \mathrm{ml} / 100 \mathrm{~g}$ dan $3 \mathrm{ml} / 100 \mathrm{~g}$ ransum, sedangkan pada penelitian Yousif (2015) level sinbiotik yang digunakan yaitu ransum basal + sinbiotik $0,5 \mathrm{mg} / \mathrm{kg}, 1 \mathrm{mg} / \mathrm{kg}$ dan $2 \mathrm{mg} / \mathrm{kg}$ ransum.

Hasil yang diperoleh menunjukkan bahwa kualitas karkas dari ayam broiler yang diberi penambahan sinbiotik semakin baik karena menghasilkan nilai nisbah yang semakin tinggi, artinya bobot dagingnya lebih tinggi. Mega et al. (2016) menyatakan bahwa nilai nisbah daging-tulang yang tinggi menunjukkan kualitas karkas yang baik karena karkas tersebut memiliki proporsi daging yang semakin tinggi. Nisbah daging dan tulang yang tinggi didukung dengan nilai bobot daging dan bobot tulang yang secara nyata $(\mathrm{P}<0,05)$ meningkat. Bobot daging dan tulang tertinggi pada perlakuan T3 yaitu $730,33 \mathrm{~g}$ dan $107,50 \mathrm{~g}$.

Dengan demikian, pada penelitian ini penambahan Sinbiotik dari IEUG dengan Lactobacillus plantarum mampu meningkatkan nisbah daging-tulang pada level minimal $3 \mathrm{ml} / 100 \mathrm{~g}$ ransum.

\section{Massa Protein Daging}

Hasil penelitian suplementasi inulin umbi Gembili dengan bakteri Lactobacillus plantarum (sinbiotik) terhadap massa protein daging karkas tersaji pada Tabel 3. Penambahan sinbiotik berpengaruh nyata $(\mathrm{P}<0,05)$ meningkatkan massa protein daging karkas ayam broiler. Peningkatan yang nyata baru terjadi pada $\mathrm{T} 2$, sedangkan $\mathrm{T} 0$ dan $\mathrm{T} 1$ tidak berbeda nyata. Nilai massa protein daging karkas berkisar antara 130,58-232,15g, tertinggi pada perlakuan T3 yaitu 232,15g.

Peningkatan nilai massa protein daging karkas ini menunjukkan bahwa penambahan sinbiotik mampu meningkatkan kecernaan dan penyerapan protein sehingga massa protein daging mengalami peningkatan. Penelitian ini sesuai dengan penelitian Abdurrahman et al. (2016) bahwa penggunaan sinbiotik dari inulin dan bakteri Lactobacillus sp. nyata meningkatkan massa protein daging.

Hal ini menunjukkan bahwa penambahan sinbiotik mampu meningkatkan jumlah BAL sehingga kecernaan dan penyerapan protein meningkat. Hal ini sesuai dengan Hafeez et al. (2017) yang menyatakan bahwa penggunaan sinbiotik akan meningkatkan penyerapan nutrien. Peningkatan penyerapan protein akan meningkatan deposisi protein kedalamjaringan otot sehingga massa protein dalam jaringan otot juga meningkat. Hal ini sesuai dengan Faradila et al. (2016) bahwa peningkatan BAL akan menurunkan $\mathrm{pH}$ sehingga penyerapan meningkat dan mengakibatkan peningkatan absorpsi protein yang mempengaruhi deposisi protein kedalam daging. Hal ini didukung dengan nilai deposisi protein yang meningkat nyata pada penelitian yang sama dan tertinggi pada perlakuan T3 sebesar 53,28\%.

Dengan demikian pada penelitian ini, penambahan sinbiotik dari inulin umbi Gembili dengan bakteri Lactobcillus plantarum mampu meningkatkan massa protein daging karkas dengan minimal dosis $3 \mathrm{ml} / 100 \mathrm{~g}$ ransum.

\section{Deposisi Protein Daging}

Hasil penelitian suplementasi inulin umbi Gembili dengan bakteri Lactobacillus plantarum (sinbiotik) terhadap deposisi 
protein daging karkas tersaji pada Tabel 3 . Penambahan sinbiotik berpengaruh nyata $(\mathrm{P}<0,05)$ meningkatkan deposisi protein daging karkas ayam broiler. Peningkatan yang nyata baru terjadi pada $\mathrm{T} 2$, sedangkan $\mathrm{T} 0$ dan T1 tidak berbeda nyata. Nilai deposisi protein daging karkas berkisar antara 40,75-53,28\%, tertinggi pada perlakuan T3 yaitu 53,28\%.

Peningkatan deposisi protein daging karkas ini menunjukkan bahwa penggunaan sinbiotik mampu meningkatkan bakteri asam laktat yang akan menurunkan $\mathrm{pH}$ usus. Penurunan $\mathrm{pH}$ akan menekan bakteri patogen dan mengaktifkan enzim-enzim pencernaan sehingga kecernaan dan penyerapan protein meningkat. Hal ini sesuai dengan Faradila et al. (2016) bahwa sinbiotik akan meningkatkan populasi bakteri asam laktat, sehingga terjadi penurunan $\mathrm{pH}$ yang akan mengaktifkan enzim pencernaan dan meningkatkan kecernaan dan penyerapan protein. Penyerapan yang meningkat ini akan meningkatkan protein yang terdeposisikan kedalam jaringan otot meningkat, sehingga nilai deposisi protein dagingnya meningkat. Deposisi protein ini nantinya akan mempengaruhi peningkatan massa protein daging di dalam karkas. Hal ini sesuai dengan Abdurrahman et al. (2016) bahwa penyerapan protein akan mempengaruhi deposisi protein menjadi massa protein daging. Hal ini didukung dengan nilai massa protein daging karkas yang nyata $(\mathrm{P}<0,05)$ meningkat, tertinggi pada perlakuan $\mathrm{T} 3$ yaitu sebesar 232,15 g.

Dengan demikian, pada penelitian ini penambahan sinbiotik dari inulin umbi Gembili dengan bakteri Lactobacillus plantarum mampu meningkatkan deposisi protein kedalam jaringan otot dengan dosis minimal $3 \mathrm{ml} / 100 \mathrm{~g}$ ransum.

\section{KESIMPULAN}

Berdasarkan hasil penelitian dapat disimpulkan bahwa penambahan sinbiotik dari IEUG dengan Lactobacillus plantarum mampu meningkatkan bobot daging, bobot tulang serta nisbah daging-tulang ayam broiler. Dosis minimal sinbiotik $3 \mathrm{ml} / 100 \mathrm{~g}$ ransum dapat digunakan sebagai aditif pakan dalam pemeliharaan ayam broiler.

\section{DAFTAR PUSTAKA}

Abdurrahman, Z. H., Y. B. Pramono, and N. Suthama. 2016. Feeding effect of inulin derived from Dahlia tuber combined with Lactobacillus sp. on meat protein mass of crossbred Kampong chicken. J. Indonesian Trop. Anim. Agric. 41(1): 37 - 44 .

Asemi, Z., M. H. Aarabi., M. Hajijafari., S. A. Alizadeh., R. Razzaghi., M. Mazoochi, and A. Esmaillzadeh. 2017. Effect of synbiotic food consumption on serum minerals, liver enzymes and blood pressure in patients with type 2 diabetes: a double-blind randomized cross-over controlled clinical trial. Int. J. Prev. Med. 8(1): 43.

Azhar, M. 2009. Inulin sebagai prebiotik. J. Saintek. 12(1): 1-8.

Beski, S. S. M. and S. Y. T. A. Sardary. 2015. Effect of dietary supplementation of probiotic and synbiotic on broiler chickens hematology and intestinal integrity. Int. J. Poult. Sci. 14(1): $31-$ 36.

Cheng, Y. F., Y. P. Chen., X. H. Li., W. L. Yang., C. Wen., Y. R. Kang., A. Q. Wang, and Y. M. Zhou. 2017. Effect of synbiotic supplementation on growth performance, carcass characteristics, meat quality and muscular antioxidant capacity and mineral contens in broilers. J. Sci. Food. Agric. 97(11): $3699-3705$.

Dibaji, S. M., A. Seidavid., L. Asadpour, and F. M. Da Silva. 2014. Effect of a synbiotic on the intestinal microflora of chickens. J. Appl. Poult.Res. 23: 1 6.

Dunislawska,A.,A. Slawinska., K. Stadnicka., 
M. Bednarczyk., P. Gulewics., D. Jozefiak, and M. Siwek. 2017. Synbiotic for broiler chickens - In vitri design and evaluation of the influence on host and selected microbiota populations following in ovo delivery. J. Plos One. 12 (1): $1-20$.

Faradila, S., N. Suthama, dan B. Sukamto. 2016. Kombinasi inulin Umbi DahliLactobacillus sp. yang mengoptimalkan perkembangan mikroflora usus dan pertumbuhan persilangan ayam PelungLeghorn. Jurnal Veteriner. 17(2): 168175.

Hafeez, H. M. A., E. S. E. Saleh., S. S. Tawfeek., I. M. I. Youssef, and A. S. A. Daim. 2017. Effect of probiotic, prebiotic and synbiotic with and without feed restriction on performance, hematological indices and carcass characteristics of broiler chickens. Asian-Australas. J. Anim. Sci. 30(5): $672-682$

Haryati, T. 2011. Probiotik dan prebiotik sebagai pakan imbuhan nonruminansia. Wartazoa. 21 (3): $125-132$.

Krismiyanto, L., N. Suthama, and H. I. Wahyuni. 2014. Feeding effect of inulin derived from Dahlia variabilis tuber on intestinal microbes in starter period of crossbred native chickens. J. Indonesian Trop. Anim. Agric. 39 (4): $217-223$.

Mega, O., B. Brata, dan J. Setianto. 2016. Penggantian sebagian ransum komersil oleh jagung dan pengaruhnya terhadap kualitas fisik daging broiler. J. IlmuIlmu Peternakan. 19 (1): 17 - 26.

Mohammed, A. A., J. A. Jacobs., G. R. Murungesan, and H. W. Cheng. 2018. Effect of dietary synbiotic supplement on behavioral pattern and growth performance of broiler chickens reared under heat stress. J. Poult. Sci. 97: $1101-1108$.

Nagara, R. L. K., S. Kismiati., S.
Setyaningrum, dan L. D. Mahfudz. 2019. Pengaruh p e $\mathrm{n}$ a $\mathrm{m}$ a h a $\mathrm{n}$ sinbiotik inulin umbi Gembili dengan Lactobacillus plantarum $\mathrm{t} \mathrm{e} \mathrm{r} \mathrm{h}$ a d a $\mathrm{p}$ massa kalsium dan protein daging. (In process).

NRC. 1994. Nutrient Requirements of Poultry. 9th Revised Edition, National Academy Press, Washington DC.

Purbarani, S. A., H. I. Wahyuni, and N. Suthama. 2019. Dahlia inulin and Lactobacillus sp. in stepp down protein diet on villi development and growth of KUB chickens. Trop. Anim. Sci. J. 42(1): $19-24$.

Rahmawati, H. G., R. Muryani, dan S. Kismiati. 2018. Pengaruh level protein dalam ransum dan lama pencahayaan terhadap bobot daging, bobot tulang dan nisbah daging tulang karkas buruh puyuh jantan. J. Peternakan Indonesia. 20(2): $70-77$.

Sabda, M., H. S. Wulanningtyas., M. Ondikeleuw, dan Y. Baliadi. 2019. Karakteristik potensi Gembili (Dioscorea esculenta L.) lokal asal Papua sebagai alternatif $\mathrm{b} a \mathrm{~h}$ a $\mathrm{n}$ pangan pokok. Buletin Plasma Nutfah. 25(1): $25-32$.

Salah, A. S., M. S. El-Tarabany, and M. A. Ali. 2018. Impact of dietary supplementation with a synbiotic, organic acids or their combination on growth performance, carcass traits, economic efficiency, jejunum histomorphometry and some blood indices of broiler chickens. Anim. Prod. Sci. 59 (7): 1318 - 1326.

Samsudin, M., W. Sarengat, dan H. N. Maulana. 2012. Pengaruh perbedaan lama periode (starter-finisher) pemberian pakan dan level protein terhadap nisbah daging tulang dan masa protein daging dada dan paha ayam pelung umur 1 minggu sampai 11 minggu. J. Animal Agricultural. 1(1): $43-51$. 
Sarangi, N. R., L. K. Babu, A. Kumar, C. R. Pradhan, P. K. Pati and J. P. Mishara. 2016. Effect of dietary supplementation of prebiotic, probiotic, and synbiotic on growth performance and carcass characteristics of broiler chickens. Vet. World. 9(16): 313 - 319.

Scholz-Ahrens, K. E., P. Ade., B. Marten., P. Weber., W. Timm., Y. Asil., C. C. Gluer, and J. Schrezenmeir. 2007. Prebiotics, probiotics and synbiotics affect mineral absorption, bone mineral conten, and bone structure. J. Nutr. 137 : 838S - 846S.

Sugiharto, S., T. Yudiarti., I. I sroli, and E. Widiastuti. 2018. Effect of feeding duration of Spirulina platensis on growth performance, haematological parameters, intestinal microbial population and carcass traits broiler chicks. South. Afric. J. Anim. Sci. 48 (1): $98-107$.

Sukmawati, N. M. S., I. P. Sampurna., M. Wirapartha., N. W. Siti, dan I. N. Ardika. 2015. Penampilan dan komposisi fisik karkas ayam kampung yang diberi jus daun pepaya terfermentasi dalam ransum komersial. J. Majalah Ilmiah Peternakan. 18(2): $39-43$.

Wirawan, I. M., I. W. Sukanata, dan M. Wirapartha. 2019. Analisis performa produksi dan pendapatan usaha ternak ayam broiler pola mandiri dengan sistem kandang terbuka (open house) (studi kasus di UD. Merta Pura Desa Meliling, Kecamatan Kerambitan,Kabupaten Tabanan). J. Peternakan Tropika. 7 (1):32 - 50.

Yang, S. C., J. Y. Chen., H. F. Shang., T. Y. Cheng., S. C. Tsou, and J. R. Chen. 2005. Effect of synbiotics on intestinal microflora and digestive enzyme activities in rats. World. J. Gastroenterology. 11(47): 7413 - 9327.

Yousif, F. O. E. 2015. Effect of Commercial Synbiotic (Bacflora) on the Performance and Carcass Characteristic of Broiler Chicks. Science and Technology for the Degree of Master, Sudan University. (Thesis).

Zubaidah, E and W. Akhadiana. 2013. Comparative study of inulin extracts from Dahlia, Yam and Gembili tubers as prebiotic. Food Nutr. Sci. J. 4: 8-12. 